\title{
Gelyktydige evaluasie van katalisators op miniatuurskaal
}

\author{
Outeurs: \\ Kariska Potgieter \\ A Aimon \\ E Smit \\ F von Delft \\ R Meijboom \\ Affiliasie: \\ Departement Chemiese \\ Wetenskappe, Universiteit \\ van Johannesburg, \\ Posbus 524, Auckland Park \\ 2006, Suid-Afrika \\ Korresponderende outeur: \\ Kariska Potgieter \\ E-pos: karisp@live.com \\ Hoe om hierdie artikel aan \\ te haal: \\ Kariska Potgieter, A Aimon, \\ E Smit, $\mathrm{F}$ von Delft, \\ R Meijboom, Gelyktydige \\ evaluasie van katalisators \\ op miniatuurskaal, Suid- \\ Afrikaanse Tydskrif vir \\ Natuurwetenskap en \\ Tegnologie 39(1) (2020). \\ https://doi.org/10.36303/ \\ SATNT.2020.39.1.826 \\ Kopiereg: \\ C) 2020. Authors. \\ Licensee: Die Suid- \\ Afrikaanse Akademie vir \\ Wetenskap en Kuns. \\ Hierdie werk is onder \\ die Creative Commons \\ Attribution License \\ gelisensieer.
}

Simultaneous evaluation of catalysts on a miniature scale: Conventional methods for catalyst discovery are tedious. By using a high-throughput system, numerous mesoporous metal oxides can be evaluated simultaneously. Miniature catalysts were synthesis on a glass plate and evaluated for the oxidation of morin. Activity was seen for all the catalyst plates (Co, Mn, $\mathrm{Co} / \mathrm{Mn}, \mathrm{Co} / \mathrm{Pd}$ and $\mathrm{Co} / \mathrm{Au})$.

Katalisators kan byna oral in die natuur gevind word en speel ' $n$ baie belangrike rol in lewende selle, asook vir mensgemaakte ingenieurswese toepassings. Katalisators word byvoorbeeld in motoruitlaatpype, die kosbedryf, vir die sintese van medisyne en brandstowwe en vir lugen watersuiweringsisteme gebruik. Katalisators bestaan uit komplekse metaal en organiese molekules, en as gevolg van die kompleksiteit is dit amper onmoontlik om 'n katalisator se aktiwiteit te voorspel. Dit maak die sintese van katalisators ook moeilik. Daarom is die ontwikkelingsproses van nuwe katalisators ingewikkeld en kan dit jare neem om nuwe katalisators te ontdek.

Heterogene katalisators is soliede katalisators, en word meestal in die industrie(ë) gebruik omdat die tipe katalisators herwin en weer gebruik kan word vir opvolgende reaksies. Dus word minder geld en tyd aan die sintese van heterogene katalisators spandeer en die afvalmateriaal word sodoende verminder. Konvensionele metodes vir die ontwikkeling van heterogene katalisators behels die sintese en evaluasie van 'n enkele katalisator per studie. Die proses is baie tydrowend en slegs ' $n$ beperkte aantal katalisators kan suksesvol ontwikkel en geëvalueer word. In hierdie studie is ' $n$ hoë-deursetting kombinatoriese sisteem ontwikkel wat die gelyktydige sintese en evaluasie van 96 verskillende heterogene mesoporeuse metaaloksiede moontlik gemaak het. Die sisteem bestaan uit 'n glasplaatjie en bodemlose putplaat met 96 holtes wat met 'n drie-dimensionele drukker vervaardig is. Nanodruppels van 'n mesoporeuse metaaloksied en/of polivinielpirolidoon (PVP) nanodeeltjie-formulerings is op 'n glasplaatjie oorgedra deur middel van 'n akoestiese vloeistofhanteerder.

Die glasplaatjie (met 96 verskillende katalisators en/of nanodeeltjie-formulerings) is aan hittebehandelings (verouder by $80^{\circ} \mathrm{C}$, gedroog by $150^{\circ} \mathrm{C}$ en gekalsineer by $400^{\circ} \mathrm{C}$ ) onderwerp om die miniatuurkatalisators te vorm. Daarna is ' $n$ aangepaste bodemlose 96 putplaat op die glasplaatjie geplak. Die stadig-drogende epoksiegom wat gebruik is, is met 'n Nordson EFD Pro-4 gomresepterende robot aangebring. Die effektiwiteit van die katalisators is geëvalueer deur die katalitiese oksidasie van morienkleurstof met waterstofperoksied as oksidant te ondersoek. Die reagense, wat insluit water, waterstofperoksied en die morienkleurstof, is deur middel van ' $n$ pipeteringsrobot in elke holte van die putplaat geplaas. Deur ' $n$ pipeteringsrobot te gebruik, kan daar verseker word dat die reagense met presisie in elke holte geplaas word. ' $\mathrm{n}$ Afname van die absorpsie van die kleurstof by $\lambda 410 \mathrm{~nm}$ is waargeneem vir al die katalisatorplate $\left(\mathrm{Co}_{3} \mathrm{O}_{4^{\prime}} \mathrm{Co}_{3} \mathrm{O}_{4} / \mathrm{MnO}_{x^{\prime}} \mathrm{Pd} / \mathrm{Co}_{3} \mathrm{O}_{4}\right.$ en $\left.\mathrm{Au} / \mathrm{Co}_{3} \mathrm{O}_{4}\right)$. Die resultate toon dat heterogene katalisators wel op miniatuurskaal gesintetiseer kan word deur ' $n$ akoestiese vloeistofhanteerder te gebruik. 'n Hoë-deursetting kombinatoriese sisteem is suksesvol gebruik vir die evaluering van heterogene mesoporeuse metaaloksiedkatalisators vir die oksidasie van morienkleurstof.

Nota: 'n Seleksie van referaatopsommings: Studentesimposium in die Natuurwetenskappe, 31 Oktober - 1 November 2019 Universiteit van die Vrystaat. Reëlingskomitee: Prof Rudi Pretorius (Departement Geografie, Universiteit van Suid-Afrika); Dr Hertzog Bisset (Suid-Afrikaanse Kernenergie-korporasie; Dr Ernie Langner (Departement Chemie, Universiteit van die Vrystaat) en Dr Wynand Nel (Departement Rekenaarwetenskap en Informatika, Universiteit van die Vrystaat). 